\title{
Ocorrência de Hematoma Peridural após Anestesia Geral Associada à Analgesia Pós-Operatória com Cateter Peridural em Paciente em Uso de Heparina de Baixo Peso Molecular. Relato de Caso *
}

\author{
Epidural Hematoma after General Anesthesia Associated with \\ Postoperative Analgesia with Epidural Catheter in Patient using Low \\ Molecular Weight Heparin. Case Report
}

Ranger Cavalcante da Silva, TSA ${ }^{1}$, André Morais e Silva², Fernando Santos Laffitte ${ }^{3}$, Gilbert Jamus ${ }^{4}$

\section{RESUMO}

Silva RC, Silva AM, Laffitte FS, Jamus G - Ocorrência de Hematoma Peridural após Anestesia Geral Associada à Analgesia Pós-Operatória com Cateter Peridural em Paciente em Uso de Heparina de Baixo Peso Molecular. Relato de Caso.

JUSTIFICATIVA E OBJETIVOS: Apresentar um caso de paciente com hematoma peridural, na vigência do uso de cateter peridural e heparina de baixo peso molecular, seu quadro clínico e tratamento.

RELATO DO CASO: Paciente do sexo feminino, 75 anos, submetida à fixação de coluna lombar por via anterior, que desenvolveu no pós-operatório quadro clínico de paralisia progressiva nos membros inferiores, com perda de sensibilidade, sem apresentar dor radicular intensa. O tratamento foi descompressão medular imediata, com drenagem e limpeza cirúrgica de hematoma peridural, que se estendia da quinta até a décima vértebra torácica. Após a drenagem do hematoma a paciente recuperou gradualmente a força nos membros inferiores, recebeu alta em 10 dias com quadro de disfunção esfincteriana. Após três meses o quadro regrediu e não houve seqüela neurológica definitiva.

CONCLUSÕES: O rápido diagnóstico com intervenção cirúrgica precoce é o tratamento mais eficaz para redução de lesão neurológica, em pacientes que desenvolvem hematoma peridural no pós-operatório. A utilização de heparina de baixo peso molecular, na vigência do uso de cateter peridural, exige a adesão estrita a protocolos estabelecidos, para que se reduzam os riscos do desenvolvimento de hematoma peridural.

\footnotetext{
* Recebido (Received from) do Hospital de Clínicas da Universidade Federal do Paraná (HC-UFPr), Curitiba, PR

1. Mestre em Medicina e Cirurgia pela Universidade Federal do Paraná; Co-Responsável pelo CET do HC-UFPr; Anestesiologista do Hospital Vita de Curitiba e Vita Batel.

2. Anestesiologista do Hospital Vita Curitiba e Vita Batel.

3. Ortopedista Cirurgião de Coluna Hospital Vita Curitiba.

4. Clínico e Cirurgião de Coluna Hospital Vita Curitiba.

Apresentado (Submitted) em 05 de julho de 2005

Aceito (Accepted) para publicação em 20 de dezembro de 2005

Endereço para correspondência (Correspondence to)

Dr. Ranger Cavalcante da Silva

R. Ângelo Sampaio 1166/401

80250-120 Curitiba, PR

E-mail: rangercavalcante@uol.com.br

(C) Sociedade Brasileira de Anestesiologia, 2006
}

Unitermos: COMPLICACCÕES: hematoma peridural; DROGAS: heparina fracionada; TÉCNICAS ANESTÉSICAS, Regional: peridural contínua.

\section{SUMMARY}

Silva RC, Silva AM, Laffitte FS, Jamus G - Epidural Hematoma after General Anesthesia Associated with Postoperative Analgesia with Epidural Catheter in Patient using Low Molecular Weight Heparin. Case Report.

BACKGROUND AND OBJECTIVES: Presents a patient case with epidural hematoma, in the course of the use of epidural catheter and low molecular weight heparin, her clinical condition and treatment.

CASE REPORT: A 75-year old female patient, submitted to the fixation of lumbar spine by anterior route, who, in the postoperative period, developed a clinical condition of progressive paralysis of the lower limbs, with loss of sensitivity and presenting no intense radicular pain. The treatment was the immediate medullar decompression, with drainage and surgical cleaning of a epidural hematoma, which extended from the $5^{\text {th }}$ to the $10^{\text {th }}$ thoracic vertebrae. After the drainage of the hematoma, the patient gradually recovered the strength in the lower limbs, was discharged in ten days with a condition of sphincterian dysfunction. After three months, the condition receded and there was no definitive neurological sequel.

CONCLUSIONS: The quick diagnosis with early surgical intervention is the most effective treatment for the reduction of neurological damage, in patients that develop postoperative epidural hematoma. The use of low molecular weight heparin, in the course of the use of epidural catheter, requires the strict compliance with the established protocols so that the risks of epidural hematoma development can be reduced.

Key Words: ANESTHETIC TECHNIQUES, Regional: continuous epidural; COMPLICATIONS: epidural hematoma; DRUGS: fractioned heparin. 


\section{INTRODUÇÃO}

A pós a introdução das heparinas de baixo peso molecular (HBPM) na prática clínica, houve aumento da incidência de hematoma peridural em pacientes cirúrgicos submetidos a anestesia regional ${ }^{1}$. O objetivo deste relato foi apresentar um caso clínico de hematoma peridural, após intervenção cirúrgica na coluna lombar, em paciente utilizando HBPM.

\section{RELATO DO CASO}

Paciente do sexo feminino, 75 anos, 40 kg, submetida à cirurgia para descompressão e fixação lombar por via ântero-lateral retroperitoneal, sob anestesia geral e com cateter peridural para analgesia pós-operatória. Apresentava na avaliação préanestésica hipertensão arterial sistêmica controlada, medicada com 50 mg de hidroclorotiazida por dia. Utilizava piroxicam, fluoxetina e cloroquina como medicações para controle de dor osteo-articular generalizada. Utilizava também o fitoterápico ginkobiloba, suspenso uma semana antes do procedimento. Os exames laboratoriais pré-operatórios eram normais com coagulograma apresentando tempo parcial de tromboplastina ativada (PTTa) de 26 segundos, teste de atividade de protrombina (TAP) de 12 segundos, contagem de plaquetas 157.000 $\mathrm{mm}^{3}$ e tempo de sangramento (TS) de cinco minutos.

Após monitorização com pressão arterial não-invasiva, cardioscópio, oxímetro de pulso, realizou-se venóclise no membro superior esquerdo com cateter 18G. Em seqüência a paciente foi posicionada em decúbito lateral esquerdo, sendo realizada punção peridural mediana em $\mathrm{T}_{10}-\mathrm{T}_{11}$, com agulha $18 \mathrm{G}$ e introdução de cateter peridural 20G, até cerca de três centímetros além da ponta da agulha. A punção foi única, sem aspiração de sangue através da agulha. Durante a operação administrou-se, pelo cateter, uma solução contendo $40 \mathrm{mg}$ de ropivacaína a $0,5 \%$ e $1 \mathrm{mg}$ de morfina. A operação teve duração de quatro horas e não houve intercorrências intra-operatórias como sangramento ou variações hemodinâmicas. Durante o procedimento a paciente foi hidratada com $2.500 \mathrm{~mL}$ de solução fisiológica a 0,9\%. Após o despertar foi encaminhada para a sala de recuperação pós-anestésica (SRPA). Na SRPA a paciente conseguia movimentar os membros inferiores e não apresentava dor. Após 1 h30 minutos foi encaminhada para o quarto. Recebeu no pós-operatório, dose única diária de enoxaparina (40 mg), para profilaxia de eventos tromboembólicos. A primeira dose de enoxaparina foi administrada oito horas após a punção peridural. Cerca de 12 horas após o procedimento o anestesiologista de plantão repetiu a morfina peridural, sem anestésico local e não houve relato de nenhum sintoma, nem foi observado déficit neurológico. Durante a madrugada do primeiro dia de pós-operatório, a paciente apresentou dificuldade progressiva para movimentar os pés, a seguir as pernas e finalmente perda da sensibilidade nos membros inferiores. Foi encaminhada, em caráter emergencial, para realização de ressonância nuclear magnética de coluna toracolombar, que identificou extenso hematoma peridural $\left(\mathrm{T}_{5}-\mathrm{T}_{10}\right)$ comprimindo a medula (Figuras 1 e 2). Foi submetida à intervenção cirúrgica descompressiva com laminectomia ampla de $\mathrm{T}_{5}$ a $\mathrm{T}_{10}$, remoção do coágulo formado, limpeza e drenagem da coluna torácica. Não foi possível identificar o local exato do sangramento. O intervalo decorrido, entre o início dos sintomas e o início da cirurgia descompressiva, foi de seis horas. Durante o procedimento cirúrgico a paciente manteve-se hemodinamicamente estável, necessitou reposição de duas unidades de concentrado de hemácias, pois sua hemoglobina inicial era de $9 \mathrm{~g} / \mathrm{dL}$. O tempo total de intervenção foi de $2 \mathrm{~h} 15$ min. Ao despertar a paciente já apresentava recuperação parcial dos movimentos nos membros inferiores, com sensibilidade alterada. Evoluiu com progressiva melhora neurológica e teve alta após 10 dias, com incontinência fecal e urinária que regrediu completamente em três meses.
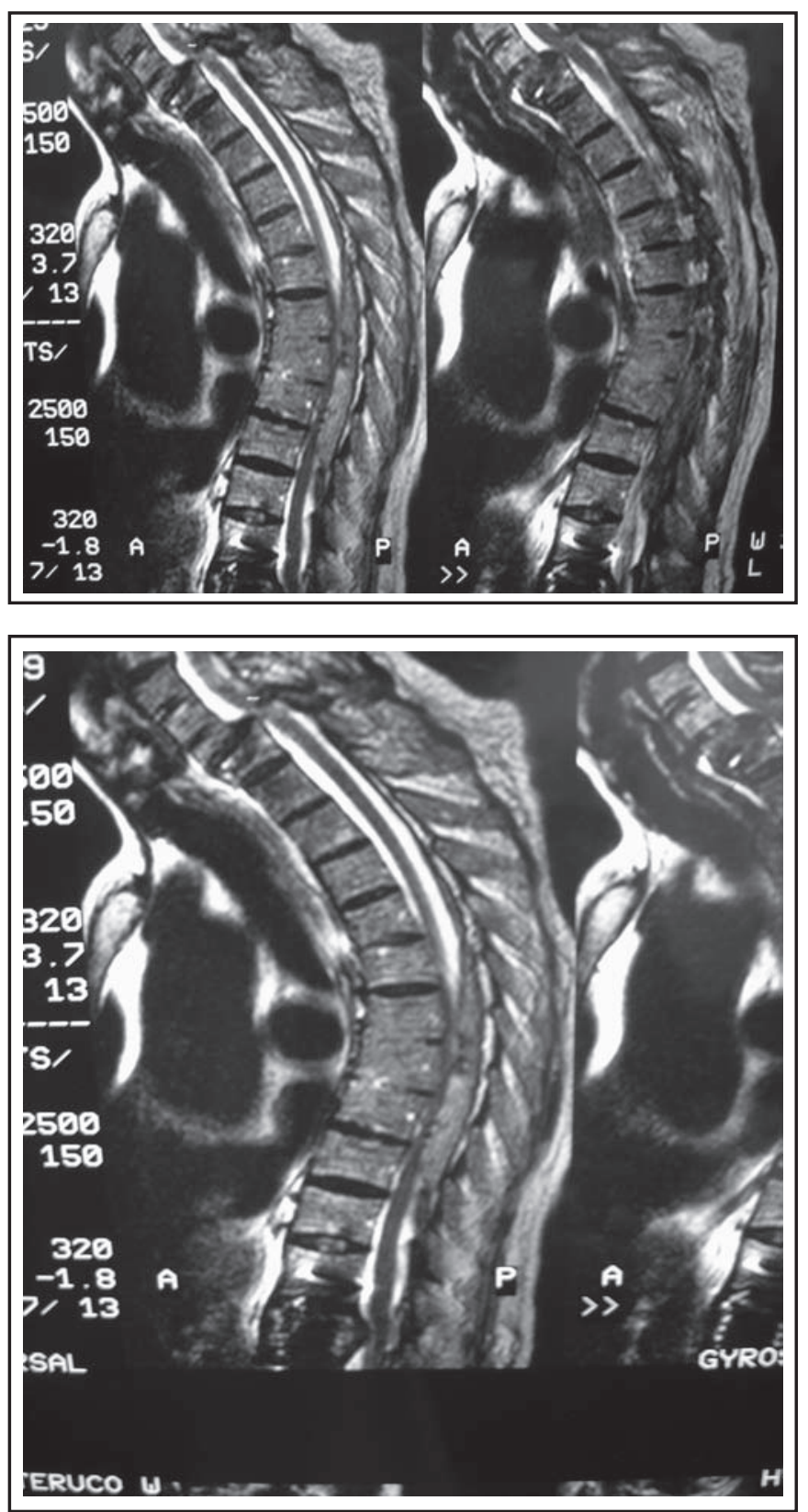

Figuras 1 e 2 - Ressonância Nuclear Magnética com Cortes Sagitais de Coluna Toracolombar, Evidenciando Extenso Hematoma Peridural da Quinta até a Décima Vértebra Torácica. 


\section{DISCUSSÃO}

A via peridural é excelente para a administração de analgésicos, pois não exige equipamentos sofisticados, o seu custo é reduzido, é segura, reduz o risco de tromboembolismo, o sangramento e o risco de transfusões sangüíneas ${ }^{1-7}$. Contudo, a utilização de peridural contínua, na vigência de HBPM exige a adesão estrita a protocolos estabelecidos, para reduzir os riscos de hematoma peridural. Outros aspectos importantes, nos pacientes utilizando HBPM são a avaliação neurológica freqüente no pós-operatório para identificar novos déficits neurológicos, o tipo de solução utilizada para analgesia de modo a não interferir com a avaliação neurológica e o momento adequado para remoção do cateter, que pode ser tão traumática quanto a punção peridural ${ }^{1}$. A incidência atual exata de déficit neurológico resultante de complicações hemorrágicas é desconhecida. A incidência citada na literatura é estimada em menos de 1:150.000 para anestesia peridural e menos que 1:220.000 para anestesia subaracnóidea ${ }^{8}$. Em pacientes com cateter peridural utilizando HBPM a incidência observada pode chegar a 1 para 3.000 , comparado com 1 para 40.000 em anestesia subaracnóidea. A estimativa é baseada nas vendas de HBPM, prevalência de anestesia subaracnóidea e casos relatados no Estados Unidos 9. É possível identificar alguns fatores de risco para o desenvolvimento de hematoma peridural, sem ser possível estratificar o risco ou a interação entre os fatores de risco ${ }^{8}$ (Quadro I).

Quadro I - Fatores Ligados ao Paciente

\begin{tabular}{|l|}
\hline Sexo feminino \\
\hline Idade avançada \\
\hline Fatores Anestésicos \\
\hline Punção e introdução traumáticas do cateter \\
\hline Peridural quando comparada à via subaracnóidea \\
\hline Cateter peridural na vigência de HBPM \\
\hline Fatores relacionados a HBPM \\
\hline Administração pré-operatória imediata ou intra-operatória \\
\hline Administração pós-operatória precoce \\
\hline Uso concomitante de antiplaquetário ou medicação anticoagulante \\
\hline Administração de HBPM duas vezes ao dia \\
\hline
\end{tabular}

Vandermeulen e col. ${ }^{11}$ após revisão da literatura entre 1906 e 1994, relataram 61 casos de hematoma peridural, associados à anestesia peridural ou subaracnóidea. Em $68 \%$ dos casos (42 pacientes) havia associação com distúrbios de coagulação. Cerca de 25 pacientes receberam heparina, por via venosa ou subcutânea. Em cinco pacientes presumiu-se o uso de heparina, por serem pacientes submetidos à cirurgias vasculares. Em 12 pacientes havia evidência de coagulopatia ou trombocitopenia ou tratamento com anticoagulante oral, antiplaquetário (aspirina, indometacina, ticlopidina), trombolíticos (urocinase) ou dextran 70 antes ou após a anestesia peridural ou espinhal. Dificuldades de punção ou passagem do cateter foram encontradas em 15 pacientes. Em 57 pacientes (87\%) havia distúrbios de coagulação ou dificuldades para punção e introdução do cateter. A evolução neurológica foi informada em 55 dos 61 pacientes que apresentaram hematoma peridural. $\mathrm{O}$ resultado neurológico foi considerado bom ou parcial em $38 \%$ dos pacientes (10/26), quando a intervenção cirúrgica ocorreu até 8 horas após o início dos sintomas (Tabela I) ${ }^{19}$. Fica evidente que os melhores resultados são obtidos a partir do rápido diagnóstico e da intervenção cirúrgica precoce.

Tabela I - Resultado Neurológico em Pacientes com Hematoma Peridural após Anestesia no Neuro-Eixo (55 em 61 pacientes)

\begin{tabular}{lccc}
\hline $\begin{array}{l}\text { Intervalo entre Início da Paraplegia e } \\
\text { a Cirurgia }\end{array}$ & $\begin{array}{c}\text { Bom } \\
\mathrm{n}=15\end{array}$ & $\begin{array}{c}\text { Parcial } \\
\mathrm{n}=11\end{array}$ & $\begin{array}{c}\text { Ruim } \\
\mathrm{n}=29\end{array}$ \\
\hline < 8 Horas $(\mathrm{n}=13)$ & 6 & 4 & 3 \\
8-24 Horas $(\mathrm{n}=7)$ & 1 & 2 & 4 \\
$>$ 24 Horas $(\mathrm{n}=12)$ & 2 & 0 & 10 \\
Não operados & 4 & 1 & 8 \\
Desconhecidos & 2 & 4 & 4 \\
\hline
\end{tabular}

Com o uso cada vez mais freqüente da HBPM e a elevação observada no número de notificações nos Estados Unidos entre 1993, ano da introdução da HBPM e 1998, com mais de 40 casos notificados ao fabricante, uma força tarefa americana desenvolveu em 1998 um protocolo, que foi atualizado em 2003, para o uso de HBPM e anestesia no neuro-eixo (Tabela II) 8 .

Tabela II - Casos de Hematoma Peridural com HBPM nos Estados Unidos entre 1993 e $1998(n=43)$

\begin{tabular}{lc}
\hline Causas & Número de Pacientes \\
\hline Espontânea & 1 \\
Cirurgia de coluna & 2 \\
Tentativas peridural/subaracnóidea & 3 \\
Injeção peridural de esteróides & 2 \\
Subaracnóidea & 6 \\
Peridural contínua & 23 \\
Condições não-especificadas & 2 \\
Técnica desconhecida & 3 \\
Total & 43 \\
\hline
\end{tabular}

Após 1998 houve nos Estados Unidos 13 casos de hematoma peridural, associados à anestesia regional. Além de HBPM, cinco pacientes receberam cetorolaco, um ibuprofeno e um heparina não fracionada por via venosa, para procedimento vascular ${ }^{11}$. 
A enoxaparina apresenta características farmacológicas distintas quando comparada à heparina não fracionada (Tabela III). Não é necessário monitorizar a resposta anticoagulante (Anti Xa), pois sua ação não é revertida pela protamina, sua meia vida é prolongada, sua ligação protéica é menor, conferindo maior estabilidade na sua biodisponibilidade 8,13 . As HBPM podem ter seus efeitos prolongados em pacientes com insuficiência renal 8,13. O uso prolongado de HBPM pode levar a acúmulo de atividade anti Xa e fibrinólise 8,13. Não está indicada a monitorização dos níveis de atividade anti Xa, por não ser índice de previsão para o risco de sangramento e, por não auxiliar no manuseio dos pacientes que receberam anestesia regional 8 .

Tabela III - Farmacologia da Enoxaparina

\begin{tabular}{|c|c|}
\hline Peso molecular & 4500 \\
\hline T $1 / 2$ anti Ila & $2,1 \mathrm{~h}$ \\
\hline $\mathrm{T} 1 / 2$ anti $\mathrm{Xa}$ & $4 \mathrm{~h}$ \\
\hline T 1/2 Plasmático & $4 \mathrm{~h}$ \\
\hline Atividade anti Xa:Ila & $4: 1$ \\
\hline Dose profilática & 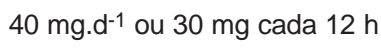 \\
\hline Dose terapêutica & $1 \mathrm{mg} \cdot \mathrm{kg}^{-1}$ cada $12 \mathrm{~h}$ \\
\hline
\end{tabular}

Em linhas gerais existem dois protocolos mais freqüentemente citados na literatura, referentes à profilaxia para fenômenos tromboembólicos, um europeu e outro americano. A Europa tem uma longa tradição de utilização de HBPM, com poucas complicações hemorrágicas 14,15 . O protocolo europeu inicia a HBPM 12 horas antes do procedimento, utilizando dose única diária de $40 \mathrm{mg}$ 17. O protocolo americano inicial introduzia a HBPM entre duas e seis horas após a cirurgia, e utilizava duas doses diárias de $30 \mathrm{mg} \mathrm{8,16.} \mathrm{Após} \mathrm{um} \mathrm{ano} \mathrm{e} \mathrm{identificados} \mathrm{dois}$ hematomas, o regime posológico recomendado foi alterado, e a primeira dose passou a ser administrada 12 a 24 horas após 0 procedimento cirúrgico ${ }^{8}$. Estudos americanos recentes demonstraram a eficácia do regime posológico único diário com dalteparina, iniciada no pós-operatório, aproximando-se do regime europeu 18. As diretrizes atualizadas da American Society of Regional Anesthesia (ASRA) sugerem a retirada do cateter peridural, duas a quatro horas antes do início do regime posológico que utiliza duas doses diárias de enoxaparina (60 mg/dia). Deste modo, não está indicada a manutenção do cateter peridural, em pacientes recebendo duas doses diárias de HBPM. Quando a punção peridural for traumática, com a presença de sangue na seringa, deve-se postergar a primeira dose de HBPM para 24 horas.

As alterações neurológicas mais freqüentes em pacientes com hematoma peridural são a perda de força nos membros inferiores, seguida de perda de sensibilidade, dor lombar e disfunção vesical. Raramente observa-se dor radicular intensa ${ }^{8}$. Com muita freqüência o diagnóstico inicial é retardado, pois o quadro é confundido com o efeito residual da anestesia ${ }^{10}$. O tratamento definitivo e com melhores resultados neurológicos é a remoção cirúrgica do hematoma, desde que feita até 8 horas após o início dos sintomas ${ }^{11}$. Existem vários protocolos para profilaxia de trombose venosa profunda, em pacientes com risco elevado para o desenvolvimento dessa complicação. Contudo, sempre que um protocolo é estabelecido, deve ser ajustado individualmente. Pacientes com idade avançada, peso muito baixo, doenças hepáticas ou renais podem apresentar respostas farmacocinéticas e farmacodinâmicas alteradas. Devem-se considerar ainda outros fármacos que possam interferir na coagulação ou até mesmo fitoterápicos, que tenham ação sobre a hemostasia (Tabela IV). Não há, até o momento, indicação de interrupção dos fitoterápicos antes de procedimentos cirúrgicos, para permitir a extinção dos seus efeitos sobre a hemostasia ${ }^{8}$. Do mesmo modo, não existem estudos suficientes que comprovem a segurança da associação de fitoterápicos e HBPM, em pacientes que receberam anestesia regional 8 .

Tabela IV - Fitoterápicos com Maior Ação na Hemostasia

\begin{tabular}{|c|c|c|c|}
\hline Fitoterápicos & Efeitos & $\begin{array}{l}\text { Problemas Peri- } \\
\text { Operatórios }\end{array}$ & $\begin{array}{l}\text { Intervalo para } \\
\text { Normalização } \\
\text { da Hemostasia }\end{array}$ \\
\hline Alho & $\begin{array}{l}\text { Inibição } \\
\text { plaquetária } \\
\text { Eleva fibrinólise }\end{array}$ & $\begin{array}{l}\text { Potencial para } \\
\text { aumentar } \\
\text { sangramento, } \\
\text { particularmente } \\
\text { quando } \\
\text { associado a } \\
\text { outros fármacos } \\
\text { que inibem } \\
\text { atividade } \\
\text { plaquetária }\end{array}$ & 7 dias \\
\hline Ginkobiloba & $\begin{array}{l}\text { Inibe fator } \\
\text { ativador } \\
\text { plaquetário }\end{array}$ & $\begin{array}{l}\text { Potencial para } \\
\text { aumentar } \\
\text { sangramento, } \\
\text { particularmente } \\
\text { quando } \\
\text { associado a } \\
\text { outros fármacos } \\
\text { que inibem } \\
\text { atividade } \\
\text { plaquetária }\end{array}$ & 36 horas \\
\hline Ginseng & $\begin{array}{l}\text { Redução da } \\
\text { glicemia } \\
\text { Eleva TAP e PTT } \\
\text { em animais }\end{array}$ & $\begin{array}{l}\text { Hipoglicemia } \\
\text { Eleva risco de } \\
\text { sangramento }\end{array}$ & 24 horas \\
\hline
\end{tabular}

A paciente foi tratada com cirurgia descompressiva, pois os sintomas iniciaram-se menos de 8 horas antes e o quadro neurológico apresentava piora progressiva. A abordagem cirúrgica mostrou-se adequada, com rápida melhora da força motora e da sensibilidade no pós-operatório imediato. A ausência de seqüelas definitivas pode ser atribuída ao rápido diagnóstico e intervenção cirúrgica. $O$ caso alerta para a necessidade de seguir protocolos rígidos quando se utiliza anestesia regional, particularmente contínua, e HBPM. A avaliação neurológica freqüente durante a manutenção do cateter, bem como após sua retirada é fundamental. Quando se utiliza anestésico local durante 
a analgesia, deve-se fazê-lo com soluções que não interfiram na avaliação da força motora, pois um dos sinais precoces do desenvolvimento de hematoma peridural é a perda da força motora nos membros inferiores. A fixação do cateter peridural, apesar de muito freqüentemente ser considerada secundária, é fundamental para que não ocorra seu deslocamento acidental, na vigência de pico de ação anticoagulante.

As intervenções cirúrgicas para descompressão e fixação lombar, realizadas por algumas equipes cirúrgicas no hospital em questão, são realizadas com anestesia geral associada à anestesia peridural contínua, para analgesia pós-operatória. Todos os pacientes submetidos à descompressão e fixação lombar, por essa equipe de cirurgia, recebem enoxaparina no pós-operatório, 40 mg uma vez ao dia, iniciando oito a 12 horas após o procedimento. Esse foi o único caso, até o momento, de hematoma peridural relacionado à anestesia regional e HBPM.

Novos medicamentos estão sendo introduzidos para a profilaxia de trombose venosa profunda como o antagonista de trombina (Ximelagatrana Exanta $\left.{ }^{\circledR}\right)$, o que irá exigir dos anestesiologistas um aprofundamento do estudo da relação custo-benefício dos referidos fármacos, bem como a adequação das diretrizes para a sua utilização em pacientes que receberam anestesia regional. A anestesia regional é segura, em pacientes que utilizam profilaxia para trombose venosa profunda com HBPM, desde que os protocolos para a sua utilização sejam seguidos e que a monitorização neurológica do paciente seja realizada regularmente, mesmo após a retirada do cateter peridural.

\section{Epidural Hematoma after General Anesthesia Associated with Postoperative Analgesia with Epidural Catheter in Patient using Low Molecular Weight Heparin. Case Report}

Ranger Cavalcante da Silva, TSA, M.D.; André Morais e Silva, M.D.; Fernando Santos Laffitte, M.D.; Gilbert Jamus, M.D.

\section{INTRODUCTION}

After the introduction of low molecular weight heparin or $(\mathrm{LMWH})$ in clinical practice, there was an increase in the incidence of epidural hematoma in surgical patients submitted to regional anesthesia ${ }^{1}$. The objective of this report was to present a clinical case of epidural hematoma, after surgery of lumbar spine, in patient using LMWH.

\section{CASE REPORT}

Female patient, 75 years old, $40 \mathrm{~kg}$, submitted to surgery for decompression and lumbar fixation by the anteriorlateral retroperitoneal route, under general anesthesia and with epidural catheter for postoperative analgesia. She presented, during the pre-anesthetic evaluation, sys- temic hypertension. She was taking treated with $50 \mathrm{mg}$ of hydrochlorothiazide per day. Piroxicam, fluoxetine, chloroquine for the control of generalized osteo-articular pain. She further used the phytotherapic drug ginkobiloba, discontinued one week before the surgery. The preoperative laboratorial exams were normal with a coagulagram presenting a activated partial thromboplastin time (APTT) of 26 seconds, prothrombin time (PT) of 12 seconds, platelet count of $157,000 \mathrm{~mm}^{3}$ and bleeding time (BT) of five minutes.

After monitoring with noninvasive arterial blood, cardioscope, pulse oximeter, venoclysis in the upper left limb was performed with an $18 \mathrm{G}$ catheter. Subsequently, the patient was positioned in a left lateral decubitus and the epidural space was acessed in $T_{10}-T_{11}$ level, with an $18 \mathrm{G}$ needle. A 20G epidural catheter was introduced 3 $\mathrm{cm}$ beyond the needle point. The puncture was single, with no aspiration of blood through the needle. During the surgery, a solution containing $40 \mathrm{mg}$ of $0,5 \%$ ropivacaine and $1 \mathrm{mg}$ of morphine was administered through the catheter. The duration of surgery was four hours and no adverse effects occurred, such as bleeding or hemodynamic instability. During the surgery, the patient was received $2,500 \mathrm{~mL}$ of saline. After the patient emerged from anesthesia, she was referred to the recovery room $(R R)$. At the RR, the patient was able to move her lower extremities and did not complain of any pain. After one hour and 30 minutes, she was sent to the ward. During the postoperative period, she was given one single daily dose of enoxaparin (40 mg), thromboembolic events prophylaxis. The first dose of enoxaparin was administered eight hours after the epidural puncture. Around 12 hours after the procedure, the anesthesiologist on duty repeated the epidural morphine without local anesthetics and there was no report of any symptom, nor was it observed any neurological deficit. During the dawn of the first postoperative day, the patient presented progressive difficulty in moving her feet, then her legs, and finally loss of sensitivity in the lower extremities. She was immediately referred to perform a magnetic nuclear resonance of the thoracic lumbar spine, which identified an extensive epidural hematoma $\left(T_{5}-T_{10}\right)$ compressing the medulla. She was submitted to decompressive surgery with wide laminectomy of $T_{5}$ to $T_{10}$, removal of the clot formed, clean and drain (Figures 1 and 2). It was not possible to identify the exact location of the bleeding. The interval between the beginning of the symptoms and the beginning of the decompressive surgery was of six hours. During the surgical procedure, the patient was kept hemodynamically stable, she received two units of packed red cells, since her initial hemoglobin was of $9 \mathrm{~g} / \mathrm{dL}$. The total time of the surgery was two hours and fifteen minutes. When she recovered from anesthesia, she already presented a partial recovery of the movements in the lower extremities, with impaired sensitivity. She evolved with progressive neurological improvement and was discharged after ten days, with fecal and urinary incontinence, which receded completely in three months. 

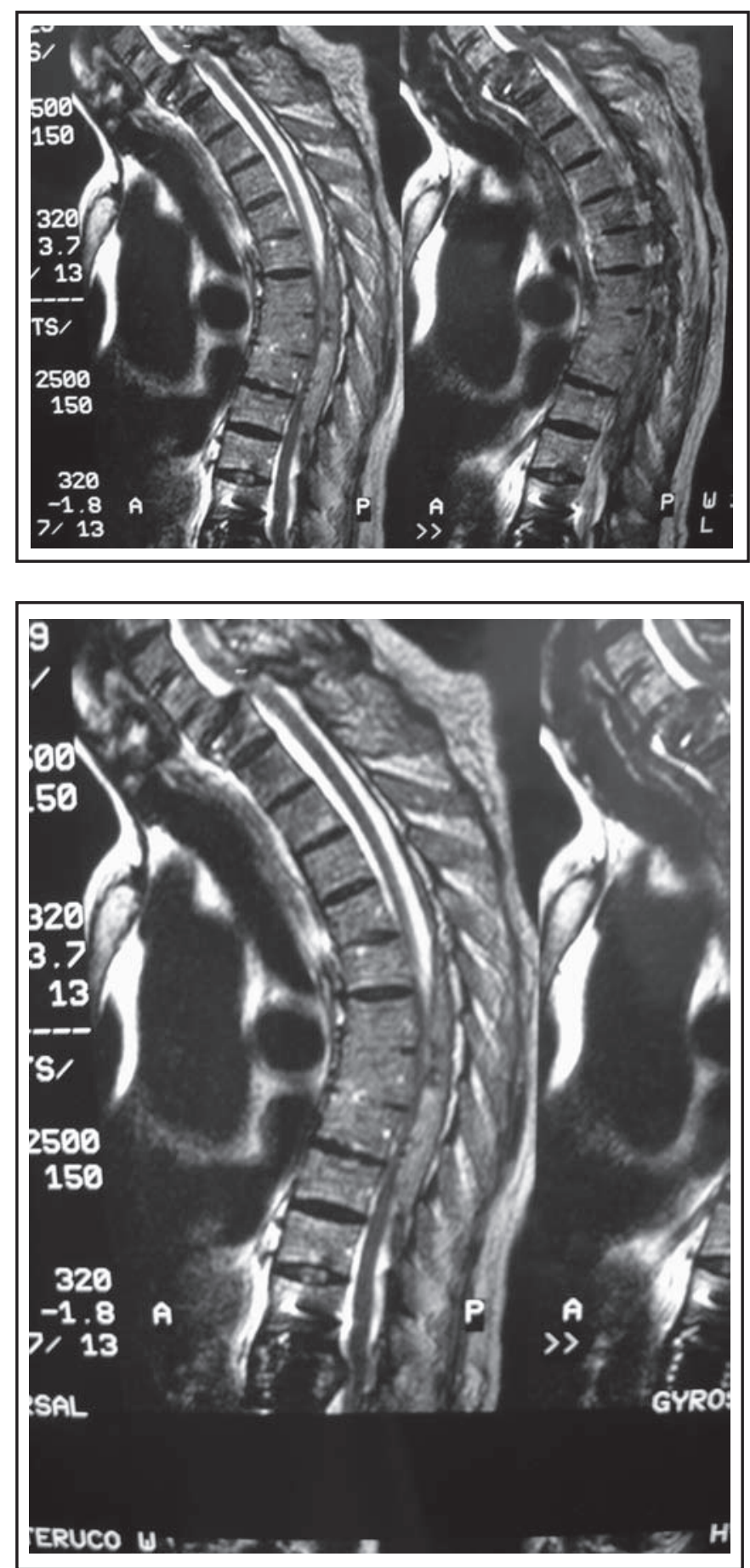

Figure 1 and 2 - Sagital recontructions of dorsal-lumbar spine MR, with evidence of an peridural hematoma from the 5th to the 10th dorsal vertebras.

\section{DISCUSSION}

The epidural route is excellent for the administration of analgesics, because it does not require sophisticated equipment, its cost is lower, it is safe, it reduces the risk of thromboembolism, it reduces bleeding and the risk of blood transfusions ${ }^{1-7}$. However, the use of continuous epidural, during the effect of LMWH, requires the strict compliance with established protocols in order to reduce the risks of epidural hematoma. Other important aspects, in the patients who use LMWH, are the frequent neurological evaluation after surgery so as to identify neurological deficits, the solution type used for analgesia so as not to interfere with the neurological evaluation and the appropriate moment to remove the catheter, which can be as traumatic as the epidural puncture 1 . The present accurate incidence of neurological deficit resulting from hemorrhagic complications is unknown. The incidence quoted in the literature is estimated in less than 1:150.000 for epidural anesthesia and less than 1:220.000 for subarachnoideal anesthesia ${ }^{8}$. In patients with epidural catheter using LMW, the incidence observed may reach 1 to 3,000 , as compared with 1 to 40,000 in subarachnoideal anesthesia. The estimate is based on the sales of LMW, prevalence of subarachnoideal anesthesia and cases reported in the United States ${ }^{9}$. It is possible to identify a few risk factors for the development of epidural hematoma and not being able to stratify the risk or the interaction between risk factors 8 (Chart I).

Chart I - Factors Related with the Patient

\begin{tabular}{|l|}
\hline Gender female \\
\hline Advanced age \\
\hline Anesthetic factors \\
\hline Traumatic puncture and introduction of the catheter \\
\hline Epidural when compared with the subarachnoideal route \\
\hline Epidural catheter during effectiveness of LMWH \\
\hline Factors related with LMWH \\
\hline Immediate preoperative or intraoperative administration \\
\hline Early postoperatory administration \\
\hline Concomitant use of antiplatelet or anticoagulant medication \\
\hline Administration of LMWH twice a day \\
\hline
\end{tabular}

Vandermeulen et al. ${ }^{11}$ after revision of the literature between 1906 and 1994, reported 61 cases of epidural hematoma, associated with epidural or subarachnoideal anesthesia. In $68 \%$ of the cases (42 patients) there was an association with coagulation disturbances. Around 25 patients received heparin, intravenously or subcutaneously. In 5 patients, the use of heparin was presumed because they were patients that had undergone vascular surgeries. In 12 patients there was evidence of coagulopathy or thrombocytopenia or treatment with oral anticoagulants, antiplatelets (aspirin, indometacin, ticlopidine), thrombolytic (urokinase) or dextran 70 before or after epidural or spinal anesthesia. Difficulty of puncture or introduction of catheter was found in 15 patients. In 57 patients $(87 \%)$, there were a coagulation disturbance or difficulties in puncturing and introducing the catheter. The neurological evolution was informed in 55 of the 61 patients who 
presented epidural hematoma. The neurological result was considered good or partial in $38 \%$ of the patients (10/26), when the surgical intervention took place up to 8 hours after the beginning of the symptoms (Table I) ${ }^{19}$. It is evident that the best results are obtained from a quick diagnostic and from an early surgical intervention.

Table I - Neurological Result in Patients with Epidural Hematoma after Neuroaxial Anesthesia (55 in 61 patients)

\begin{tabular}{lccc}
\hline $\begin{array}{l}\text { Interval between the Beginning of } \\
\text { the Paraplegia and the Surgery }\end{array}$ & $\begin{array}{c}\text { Good } \\
\mathrm{n}=12\end{array}$ & $\begin{array}{c}\text { Partial } \\
\mathrm{n}=11\end{array}$ & $\begin{array}{c}\text { Bad } \\
\mathrm{n}=29\end{array}$ \\
\hline$<8$ Hours $(\mathrm{n}=13)$ & 6 & 4 & 3 \\
8-24 Hours $(\mathrm{n}=7)$ & 1 & 2 & 4 \\
$>$ 24 Hours $(\mathrm{n}=12)$ & 2 & 0 & 10 \\
Not operated & 4 & 1 & 8 \\
Unknown & 2 & 4 & 4 \\
\hline
\end{tabular}

With the increasing use of LMWH it was observed an increase in the number of notifications in the United States between 1993, year when the LMWH was introduced, and 1998, with more than 40 cases notified to the manufacturer. An American task force, in 1998 developed a protocol, which was updated in 2003, for the use of LMWH and anesthesia in the neuraxial (Table II) 8 .

Table II - Cases of LMWH Epidural Hematoma in the United States between 1993 and $1998(n=43)$

\begin{tabular}{lc}
\hline Causes & Number of Patients \\
\hline Spontaneous & 1 \\
Column surgery & 2 \\
Epidural/spinal attempts & 3 \\
Epidural injection of steroids & 2 \\
Spinal & 6 \\
Continuous Epidural & 23 \\
Non specified conditions & 2 \\
Unknown technique & 3 \\
Total & 43 \\
\hline
\end{tabular}

After 1998, there were 13 cases of epidural hematoma associated with regional anesthesia in the United States. In addition to $\mathrm{LMWH}$, five patients received ketorolac, one received ibuprophen and one received non fractioned heparin intravenously, for a vascular procedure ${ }^{11}$.

The enoxaparin presents distinct pharmacological characteristics when compared with the non fractioned heparin (Table III). It is not necessary to monitor the anticoagulant response (Anti $\mathrm{Xa}$ ), its action is not reverted by protamine, its half-life is longer, its protein binding is smaller, conferring more stability in its bioavailability 8,13 . The LMWH may have its effects prolonged in patients with renal insufficiency 8,13. The prolonged use of LMWH may lead to an accumulation of anti Xa activity and fibrinolysis 8,13 . The monitoring of the levels of anti Xa activity is not recommended because it is not an index for estimate the bleeding risk and because it does not help in handling the patients who received regional anesthesia 8 .

Table III - Pharmacology of Enoxaparin

\begin{tabular}{|c|c|}
\hline Molecular Weight & 4500 \\
\hline T $1 / 2$ anti Ila & $2,1 \mathrm{~h}$ \\
\hline $\mathrm{T} 1 / 2$ anti $\mathrm{Xa}$ & $4 \mathrm{~h}$ \\
\hline T $1 / 2$ plasmatic & $4 \mathrm{~h}$ \\
\hline Anti Xa activity: Ila & $4: 1$ \\
\hline Prophylactic dosage & 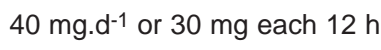 \\
\hline Therapeutic dosage & $1 \mathrm{mg} \cdot \mathrm{kg}^{-1}$ each $12 \mathrm{~h}$ \\
\hline
\end{tabular}

In general, there are two protocols that are most frequented quoted in the literature relative to the prophylaxis of the thromboembolic phenomena. One is European and the other is American. Europe has a long tradition in the use of LMWH, with few hemorrhagic complications 14,15 . The European protocol starts LMWH 12 hours before the procedure, using a single daily dose of $40 \mathrm{mg}$ 17. The initial American protocol introduced LMWH two to six hours after surgery and used two daily doses of $30 \mathrm{mg} \mathrm{8,16}$. After one year and two hematomas, the posological regimen recommended was changed and the first dose started to be administered 12 to 24 hours after the surgical procedure ${ }^{8}$. Recent American studies have shown the efficacy of the single daily posological regimen with dalteparin, started during the postoperative period, nearing the European regimen ${ }^{18}$. The updated guidelines of the American Society of Regional Anesthesia (ASRA) suggest the removal of the epidural catheter from two to four hours before the beginning of the posological regimen that uses two daily doses of enoxaparin $(60 \mathrm{mg} /$ day). This way, the maintenance of the epidural catheter is not recommended in patients receiving two daily doses of $\mathrm{LMWH}$. When the epidural puncture is traumatic, with the presence of blood in the syringe, the first dose of LMWH should be postponed for 24 hours.

The most frequent neurological changes in patients with epidural hematoma are the loss of strength in the lower limbs, followed by loss of sensitivity, lumbar pain and vesical dysfunction. Intense radicular pain is rarely observed 8 . Quite often, the initial diagnostic is delayed because the picture is thought to be a residual anesthesia effect ${ }^{10}$. The final treatment and that with the best neurological results is the surgical evacuation of the hematoma, as long as it is performed up to 8 hours after the beginning of the symptoms 11 . There are several protocols for the prophylaxis of deep vein thrombosis in patients with high risk for the development of this complication. However, whenever a protocol is established, we must adjust it individually. Patients at an advanced age, very low weight, hepatic or renal diseases, may present altered pharmacoki- 


\section{EPIDURAL HEMATOMA AFTER GENERAL ANESTHESIA ASSOCIATED WITH POSTOPERATIVE ANALGESIA WITH EPIDURAL CATHETER IN PATIENT USING LOW MOLECULAR WEIGHT HEPARIN. CASE REPORT}

netic and pharmacodynamic responses. In addition, one must also take into consideration other pharmaceutical substances that might interfere with the coagulation or even the phytotherapic drugs that have action on the hemostasy (Table IV). Up to the present time, there is no indication for the interruption of the phytotherapic drugs before surgical procedures, to allow the extinction of their effects on hemostasy ${ }^{8}$. Similarly, there are not sufficient studies confirming the safety of the association of phytotherapic drugs and LMWH in patients that received regional anesthesia 8 .

The patient was treated with decompressive surgery because the symptoms started less than 8 hours before and the neurological picture presented progressive worsening. The surgical approach proved to be appropriate, with a rapid improvement of the motor strength and the sensitivity in the immediate period after surgery. The absence of definitive sequels can be attributed to a fast diagnostic and surgical intervention. The case alerts to the need of following rigid protocols when one uses regional anesthesia, particularly the continuous one, and $\mathrm{LMWH}$. The frequent neurological evaluation during the maintenance of the catheter, as well as after it is removed, is fundamental. When one uses local anesthetic during analgesia, this must be done with solutions that do not interfere with the evaluation of the motor strength, since one of the early signs of the development of a epidural hematoma is the loss of motor strength in the lower limbs. The fixation of the epidural catheter, although this is quite frequently considered secondary, is fundamental so that there is no accidental dislocation of the catheter during the peak of anticoagulant action.

Table IV - Phytotherapics with Highest Effect on Hemostasy

\begin{tabular}{|c|c|c|c|}
\hline Phytotherapics & Effects & $\begin{array}{l}\text { Perioperative } \\
\text { Problems }\end{array}$ & $\begin{array}{l}\text { Interval for the } \\
\text { Normalization } \\
\text { of the } \\
\text { Hemostasy }\end{array}$ \\
\hline Garlic & $\begin{array}{l}\text { Platelet } \\
\text { inhibition } \\
\text { increases } \\
\text { fibrinolysis }\end{array}$ & $\begin{array}{l}\text { Potential } \\
\text { to increase } \\
\text { bleeding, } \\
\text { particularly } \\
\text { when } \\
\text { associated with } \\
\text { other drugs } \\
\text { that inhibit } \\
\text { platelet activity }\end{array}$ & 7 days \\
\hline Ginkobiloba & $\begin{array}{l}\text { Inhibits platelet } \\
\text { activating factor }\end{array}$ & $\begin{array}{l}\text { Potential } \\
\text { to increase } \\
\text { bleeding, } \\
\text { particularly } \\
\text { when } \\
\text { associated with } \\
\text { other drugs } \\
\text { that inhibit } \\
\text { platelet activity }\end{array}$ & 36 hours \\
\hline Ginseng & $\begin{array}{l}\text { Reduction of } \\
\text { glycemia } \\
\text { Increases TAP } \\
\text { and PTT in } \\
\text { animals }\end{array}$ & $\begin{array}{l}\text { Hypoglycemia } \\
\text { Increases risk } \\
\text { of bleeding }\end{array}$ & 24 hours \\
\hline
\end{tabular}

The surgical interventions for decompression and lumbar fixation, performed by a few surgical teams at our hospital, are performed with general anesthesia associated with continuous epidural anesthesia, for postoperatory analgesia. All the patients submitted to decompression and lumbar fixation, by this surgical team, receive enoxaparin during the postoperative, $40 \mathrm{mg}$ once a day, started from 8 to 12 hours after the procedure. This was the only case, up to the present time, of epidural hematoma associated with regional anesthesia and LMWH.

New medications are being introduced for the prophylaxis of deep vein thrombosis as the thrombolytic antagonist (Ximelagatrana Exanta $\left.{ }^{\circledR}\right)$, which will require, from the anesthesiologists, further studies of the cost/benefit relation of the referred to pharmaceutical drugs, as well as the adequacy of guidelines for their use in patients who received regional anesthesia. The regional anesthesia is safe in patients who use prophylaxis for deep vein thrombosis with LMWH, as long as the protocols for their use are followed and that neurological monitoring of the patient is performed regularly, even after the removal of the epidural catheter.

\section{REFERÊNCIAS - REFERENCES}

01. Horlocker TT, Wedel DJ - Neuraxial block and low molecular weight heparin: balancing perioperative analgesia and thromboprophylaxis. Reg Anesth Pain Med, 1998;23:164-177.

02. Liu SS, Carpenter RL, Neal JM - Epidural anesthesia and analgesia. Their role in postoperative outcome. Anesthesiology, 1995;82:1474-1506.

03. Wu CL, Fleisher LA - Outcomes research in regional anesthesia and analgesia. Anesth Analg, 2000;91:1232-1242.

04. Modig J, Borg T, Karlstrom G et al - Thromboembolism after total hip replacement: role of epidural and general anesthesia. Anesth Analg, 1983;62:174-180.

05. Yeager M, Glass D, Neff $R$ et al - Epidural anesthesia and analgesia in high-risk surgical patients. Anesthesiology, 1987;66:723-724.

06. Christopherson R, Beattie C, Frank S et al - Perioperative morbidity in patients randomized to epidural or general anesthesia for lower extremity vascular surgery. Anesthesiology, 1993;79:422-434.

07. Rosenfeld B, Beattie C, Christopherson R et al - The effects of different anesthetic regimens on fibrinolysis and the development of postoperative arterial thrombosis. Anesthesiology, 1993;79:435-443.

08. Horlocker TT, Wedel DJ, Benzon $\mathrm{H}$ et al - Regional anesthesia in the anticoagulated patient: defining the risks (the second ASRA Consensus Conference on Neuraxial Anesthesia and Anticoagulation). Reg Anesth Pain Med, 2003;28:172-197.

09. Cheney FW, Domino KB, Caplan RA et al - Nerve injury associated with anesthesia: a closed claims analysis. Anesthesiology, 1999;90:1062-1069.

10. Schroeder DR - Statistics: detecting a rare adverse drug reaction using spontaneous reports. Reg Anesth Pain Med, 1998;23:183-189.

11. Litz RJ, Hubler M, Koch T et al - Spinal epidural hematoma following epidural anesthesia in the presence of antiplatelet and heparin therapy. Anesthesiology, 2001;95:1031-1033.

12. Vandermeulen EP, Van Aken $\mathrm{H}$, Vermylen $\mathrm{J}$ - Anticoagulants and spinal anesthesia. Anesth Analg, 1994;79:1165-1177. 
13. Majed A-H, Anthony JM - The pharmacology of antithrombotic and antiplatelet agents. Anesthesiol Clin North Am, 1999;17:749-786.

14. Bergqvist $D$, Lindblad $B$, Matszch $T$ - Low molecular weight heparin for tromboprophylaxis and epidural/spinal anesthesia. Is there a risk? Acta Anaesthesiol Scand, 1992;36:605-609.

15. Mismetti P, Laporte S, Darmon JY et al. - Meta-analysis of low molecular weight heparin in the prevention of venous thromboembolism in general surgery. Br J Surg, 2001;88:913-930.

16. Hull RD, Pineo GF, Stein PD et al - Timing of initial administration of low molecular weight heparin prophylaxis against deep vein thrombosis in patients following elective hip arthroplasty: a systematic review. Arch Intern Med, 2001;161:1952-1960.

17. Tryba M, Wedel DJ - Central neuraxial block and low molecular weight heparin (enoxaparin): lessons learned from two different dosage regimes in two continents. Acta Anaesthesiol Scand, 1997;41:100-104.

18. Hull RD, Pineo GF, Francis $C$ et al - Low-molecular-weight heparin prophylaxis using dalteparin in close proximity to surgery versus warfarin in hip arthroplasty patients: a double-blind, randomized comparison. The North American Fragmin Trial Investigators. Arch Intern Med, 2000;160:2199-2207.

19. Horloker TT - Anticoagulation an neuraxial anesthesia. Anesthesiol Clin North Am, 1999;17:861-879.

\section{RESUMEN}

Silva RC, Silva AM, Laffitte FS, Jamus G - Ocurrencia de Hematoma Postanestesia General Asociada a Analgesia Postoperatoria con Cateter Peridural en Paciente que Usa Heparina de Bajo Peso Molecular. Relato de Caso

JUSTIFICATIVA Y OBJETIVOS: presentar el caso de una paciente con hematoma peridural, con uso actual de catéter peridural y heparina de bajo peso molecular, su cuadro clínico y tratamiento. RELATO DEL CASO: Paciente de 75 años, sometida a la fijación de columna lumbar por vía anterior, que desarrolló en el postoperatorio un cuadro clínico de parálisis progresiva en los miembros inferiores, con pérdida de la sensibilidad, sin presentar dolor radicular intenso. El tratamiento fue descompresión medular inmediata, con drenaje y limpieza quirúrgica de un hematoma peridural, que se extendía desde la quinta hasta la décima vértebra toráxica. Después del drenaje del hematoma la paciente recuperó gradualmente la fuerza en los miembros inferiores, recibió alta en diez días con cuadro de disfunción de esfínteres. Después de tres meses el cuadro remitió y no hubo secuela neurológica definitiva.

CONCLUSIONES: El rápido diagnóstico con intervención quirúrgica precoz es el tratamiento más eficaz para la reducción de la lesión neurológica, en pacientes que desarrollan hematoma peridural postoperatorio. La utilización de heparina de bajo peso molecular, con uso actual de catéter peridural, exige la adhesión estricta a protocolos establecidos, para que se reduzcan los riesgos del desarrollo de hematoma peridural. 